\title{
Increased production of GABA in non-alcoholic Makgeolli by optimization of lactic acid fermentation using Lactobacillus plantarum
}

\author{
Ji-Yeon Choe ${ }^{1}$, Jong-Soon $\mathrm{Lim}^{2}$, Sam-Pin Lee $\mathrm{Le}^{1,2 *}$ \\ ${ }^{1}$ Department of Food Science and Technology, Keimyung University, Daegu 42601, Korea \\ ${ }^{2}$ The Center for Traditional Microorganism Resource, Keimyung University, Daegu 42601, Korea
}

비알콜 쌀막걸리의 젖산 발효 최적화를 통한 고농도 GABA 생산

\author{
최지연 ${ }^{1} \cdot$ 임종순 $^{2} \cdot$ 이삼빈 ${ }^{1,2 *}$ \\ ${ }^{1}$ 계명대학교 식품가공학과, ${ }^{2}$ 계명대학교 TMR센터
}

\begin{abstract}
Lactic acid fermentation of non-alcoholic Makgeolli a traditional Korean rice wine was optimized for increased production of $\mathrm{z}$-aminobutyric acid (GABA). The Makgeolli was concentrated by vacuum evaporation at $85^{\circ} \mathrm{C}$ for 30 min to yield non-alcoholic Makgeolli and sterilize the indigenous microorganisms. As a result, yeast and lactic acid bacteria were not observed in the non-alcoholic Makgeolli. The non-alcoholic Makgeolli had an unpleasant odor in the absence of glucose in lactic acid fermentation. Therefore, the non-alcoholic Makgeolli was mixed with 3\% mono sodium-L-glutamate (MSG) and 1\% glucose followed by fermentation with Lactobacillus plantarum EJ2014 at $30^{\circ} \mathrm{C}$ for 7 days in stationary culture. During this period, the $\mathbf{p H}$ increased from 5.1 to 5.5 and acidity decreased from $0.41 \%$ to $0.2 \%$. The viable cell count increased to $3.0 \times 10^{8} \mathrm{CFU} / \mathrm{mL}$ by the end of the 7 day period. The production was determined using TLC; results showed that Most of the MSG was bio-converted on within 5 days. of lactic acid fermentation. HPLC analysis confirmed GABA production 1.59\%. In conclusion, non-alcoholic Makgeolli with $1 \%$ glucose and $3 \%$ MSG could produce functional rice ingredients including GABA and probiotics as well as wholesome rice products through lactic acid fermentation.
\end{abstract}

Key words : Lactobacillus plantarum, lactic acid fermentation, Makgolli, GABA

\section{서 론}

막걸리 또는 탁주는 찹쌀, 멥쌀, 밀 및 국을 주원료로 혼합한 후 병행 복발효하여 만든 대표적인 전통주이다. 전 통 누룩을 이용한 전통 막걸리는 고유한 품질특성을 가지고 있으며, 곰팡이 배양물을 효소원으로 사용하는 코지를 이 용하여 제조한 막걸리와 맛과 품질관리에서 차이가 있다. 막걸리는 다른 알코올성 음료들과는 달리 효모와 젖산균 등의 probiotic과 유기산이 함유되어 있을 뿐만 아니라 단백

*Corresponding author. E-mail : splee@kmu.ac.kr Phone : 82-53-580-5554, Fax: 82-53-580-6447

Received 20 November 2018; Revised 31 December 2018; Accepted 10 January 2019.

Copyright (c) The Korean Society of Food Preservation. All rights reserved.
질과 당, 식이섬유, 비타민을 비롯하여 다양한 영양성분과 발효에 의한 대사산물을 함유하고 있다(1).

고령화시대에 건강장수에 대한 관심이 높아지고 국내외 적으로 우리나라 전통 발효식품에 대한 관심이 증대됨에 따라 막걸리에 관한 다양한 연구가 진행되어왔다. 막걸리 는 혈전 용해 활성과 타이로시네이즈 저해 활성, 혈압 강하 효과와 혈당 저하 효과(2,3), 항비만, 항염증, 항암 효과 $(4,5)$ 등이 있다고 보고되었다. 최근 막걸리에서 항암 작용이 있 는 farnesol성분이 발견되었고(6), 피부 재생과 미백, 피로회 복, 콜레스테롤 저하 효과 등에 관한 연구(7)가 보고되었다.

건강 바이오소재의 개발을 위한 방법으로 천연물에 발효 기술을 적용하는 시도가 증가하고 있으며, 발효 미생물은 원료에 작용하여 풍미와 기능성을 향상시키고, 동시에 저 장성을 높이는 역할을 한다(8). 특히 젖산균 Lactobacillus spp.는 대표적인 probiotic으로서 당질을 이용하여 그 대사 
산물로 유기산 등을 생성하고, 정장 작용 및 면역 증진 효과 가 있다고 밝혀지면서 건강 기능성 소재로서 관심이 높아지 고 있다(9).

상업적으로 생산되는 막걸리는 쌀 코지에서 배양된 곰팡 이 유래 효소작용 및 효모의 대사산물을 함유하고 있어서 유용 미생물의 배양을 위해 필요한 탄소원을 비롯하여 다양 한 영양성분 등이 다량 함유된 것으로 보고되었다(10). 코지 를 이용하여 제조된 막걸리는 젖산균이 미미하게 존재하 며, probiotic을 포함한 기능성 성분의 강화를 통해 막걸리의 영양적 및 기능성을 부여하는 것이 필요하다. 또한 1 인당 쌀 소비량이 지속적으로 감소하고 있는 가운데 쌀을 이용한 기능성 강화소재의 개발은 쌀 소비 촉진과 동시에 고부가가 치 발효소재를 개발하는 의미가 있다.

Lactobacillus plantarum 균주가 생성하는 8 -aminobutyric $\operatorname{acid}(\mathrm{GABA})$ 는 고등동물의 뇌나 척수 등의 중추 신경계에 존재하는 흥분 억제성 신경 전달 물질로, 자연계에 분포하 는 비단백질 아미노산의 일종이다(11,12). GABA는 뇌의 혈류를 활발하게 하고 뇌세포의 대사기능을 촉진시키는 기능이 있으며, 혈압강하 효과, 이뇨 효과, 진정 효과, 암 세포 억제 효과, 정신 분열증을 비롯한 신경질환과 우울증 및 자율 신경 장애에 효과가 있는 등의 생리 기능이 있다 $(13,14)$. 천연물 중에서는 주로 발아 현미, 뽕잎, 녹차 등에 자연적으로 약간 함유되어 있다(15). 발효를 통해 $\mathrm{GABA}$ 의 함량을 높이는 방법으로 양송이에서 분리된 젖산균을 이용 하여 MSG존재 하에서 $\mathrm{GABA}$ 의 함량을 높이는 방법(16), 카카오 추출물에 dextrose를 첨가한 후 젖산 발효 하여 $\mathrm{GABA}$ 를 생산하는 방법(15), 찻잎에 혐기적 배양과 호기적 배양을 번갈아 처리하여 GABA 함량을 높이는 방법(17) 등이 보고되었다. 최근 다양한 생리 활성 기능을 갖는 $\mathrm{GABA}$ 의 생산을 높이기 위해서 유용 발효 미생물의 활용한 연구가 활발하게 진행되고 있으며, 특히 젖산균을 이용한 $\mathrm{GABA}$ 생산의 최적화를 통해서 기능성을 강화시킨 기능성 소재를 개발하려는 연구가 진행되고 있다.

본 연구에서는 쌀 소비 촉진 및 쌀의 부가가치를 높이는 방안으로 쌀 막걸리 제품을 이용하여 기능성을 강화시키고 자 하였으며, 이를 위해 알코올이 제거된 쌀 막걸리 발효물 의 젖산균 발효 최적화를 통해서 기능성 물질 $\mathrm{GABA}$ 와 probiotic이 강화된 기능성 쌀 발효물을 생산하고자 하였다.

\section{재료 및 방법}

\section{재 료}

본 연구의 원료로는 대구 탁주(Daegu, Korea)의 생막걸 리를 구입하여 $85^{\circ} \mathrm{C}$ 에서 진공 농축하여 사용하였다. 젖산 발효 시 영양 성분으로 사용된 포도당은 삼양식품(주) (Seongnam, Korea)에서 구입하였고, $\mathrm{\gamma}$-aminobutyric acid
(GABA) 생성을 위한 전구물질로 사용된 monosodium L-glutamate(MSG)는 CJ 제일제 당(주(Incheon, Korea)의 제 품을 사용하였다. MRS broth는 Difco $^{\mathrm{TM}}$ Lactobacilli MRS(Becton Dicknson and Company, Sparks, MD, USA)사 의 제품을 사용하였다.

\section{균주 및 스타터 배양액 제조}

Lactobacillus plantarum EJ2014는 미강(Uljin, Korea)으 로부터 분리한 균주를 한국미생물보존센터에 기탁(KCCM $11545 \mathrm{P}$ )한 후 분양받아 사용하였다. L. plantarum EJ2014를 MRS agar plate에서 계대배양한 후 $121^{\circ} \mathrm{C}$ 에서 15 분간 살균 한 MRS broth에 순수 배양된 L plantarum EJ2014 한 백금이 를 접종하고 $30^{\circ} \mathrm{C}$ 에서 24 시간 동안 정치 배양하여 starter로 사용하였다(18).

\section{비알코올 막걸리의 젖산 발효물 제조}

젖산균의 생육을 저해하는 효모의 활성을 낮추고, 알코 올을 제거하기 위하여 쌀 막걸리를 $85^{\circ} \mathrm{C}$ 에서 30 분간 진공 농축하고, 실험의 일관성을 위해서 증발된 막걸리의 양만 큼 멸균수를 첨가하여 비알코올 막걸리(non-alcohol Makgeolli, $\mathrm{NAM}$ )를 제조하였다. 비알코올 막걸리는 멸균수와 $\mathrm{MSG}$, 포도당 0-5\%를 혼합하여 총 부피를 $100 \mathrm{~mL}$ 로 맞추어 250 $\mathrm{mL}$ 삼각 플라스크에 채웠다. GABA 생산의 기질인 MSG와 탄소원으로 포도당은 첨가 농도를 달리하여 발효 최적화를 수행하였다. L. plantarum EJ2014 배양액을 1\% 수준으로 접종한 후 항온배양기에서 $30^{\circ} \mathrm{C}$ 에서 7 일간 정치 배양하였 다.

\section{고형분 함량 분석}

막걸리의 고형분 함량은 상압 가열 건조법(19)을 이용하 여 수분 함량을 5 회 반복 측정한 후 그 평균값을 100 에서 제외한 값으로 산출하였다. 수분 함량은 시료 $3 \mathrm{~mL}$ 을 항량 된 칭량 접시에 담은 후 $105^{\circ} \mathrm{C}$ 건조기(HB-502n, Hanbaek Scientific Co., Bucheon, Korea)에서 건조하여 항량된 무게 를 측정하였다.

\section{$\mathrm{pH}$ 및 적정 산도 측정}

생막걸리 및 비알코올 막걸리 젖산 발효물의 $\mathrm{pH}$ 는 시료 $1 \mathrm{~mL}$ 에 증류수 $9 \mathrm{~mL}$ 을 가하여 희석한 후 $\mathrm{pH}$ meter (SevenEasy, Mettler-Toledo AG, Schwerzenbach, Switzerland) 를 이용하여 측정하였다. 적정 산도 $\mathrm{pH} 8.3$ 에 도달할 때까지 $0.1 \mathrm{~N} \mathrm{NaOH}$ 로 적정하여 소비량을 lactic acid 함량(\%, v/v)으 로 환산하여 산출하였다(20).

\section{생균수 측정}

생균수는 10 배 희석법을 이용하여 비알코올 막걸리 젖산 발효물 $100 \mu \mathrm{L}$ 에 멸균수 $900 \mu \mathrm{L}$ 을 첨가해서 $10^{4}, 10^{5}, 10^{6}$ 배 
로 희석한 것을 MRS agar plate에 $20 \mu \mathrm{L}$ 도말하였다. 그 후 $30^{\circ} \mathrm{C}$ 항온배양기에서 24 시간 배양한 다음 측정하여 colony forming unit(CFU)/mL로 나타내었다.

\section{환원당 함량 측정}

환원당의 함량은 dinitrosalicylic acid(DNS)법(21)을 통해 분석하였다. 일정한 농도로 희석한 시료 $1 \mathrm{~mL}$ 에 DNS시약 $3 \mathrm{~mL}$ 를 가하여 끓는 물에서 5 분간 반응시키고 40 분 동안 방냉한 후 UV spectrophotometer(Ultrospec ${ }^{\circledR} 2100$ pro, Amersham Biosciences, Waltham, MA, USA)를 이용하여 $550 \mathrm{~nm}$ 에서 측정하였다. 표준시료로는 glucose(SigmaAldrich, St. Louis, MO, USA)를 사용하였다

\section{TLC를 이용한 GABA 및 glutamic acid 정성 분석}

MSG 분해 정도와 GABA 생성능 비교를 위한 standard로 는 glutamic acid와 GABA를 Sigma-Aldrich에서 구입하여 $0.5 \%$ 농도로 사용하였다. TLC 전개는 사각 chamber $\left(30 \times 25 \times 10 \mathrm{~cm}^{3}\right)$ 에서 수행하고, silica gel TLC plate는 $10 \times 20$ $\mathrm{cm}$ 의 크기로 잘라서 사용하였다. 전개용매는 $\mathrm{n}$-butyl alcohol:acetic acid glacial:distilled water를 각각 $3: 1: 1(\mathrm{v} / \mathrm{v})$ 의 비율로 혼합하여 실온에서 4시간 이상 포화시켰다. 각 sample은 TLC plate의 끝에서 $15 \mathrm{~mm}$ 되는 위치에 $2 \mu \mathrm{L}$ 를 점적, sample 간격은 $10 \mathrm{~mm}$ 를 유지하였다. 점적 후 $\mathrm{TLC}$ plate의 sample을 건조 시키고, 전개가 끝난 TLC plate는 실온에서 건조시켰다. 건조 된 TLC plate에 발색시약 $0.2 \%$ ninhydrin을 뿌리고, $90^{\circ} \mathrm{C}$ dry oven에서 5-10분 동안 발색 시킨 후 각각의 spot을 확인하였다.

\section{$\mathrm{HPLC}$ 를 이용한 GABA 정량분석}

GABA 전환율을 확인하기 위한 유리 아미노산 함량 측정 은 건조시킨 시료를 phenylisothiocyanate(PITC)용액 $20 \mu$ $\mathrm{L}\left(\mathrm{MeOH}: \mathrm{H}_{2} \mathrm{O}: \mathrm{TEA}: \mathrm{PITC}=7: 1: 1: 1\right)$ 를 유도체화 시킨 뒤 상온 에서 30 분간 반응 시켰다. 시료를 완전히 건조시킨 후 200 $\mu \mathrm{L}$ 의 A solvent로 녹이고 원심분리한 후 상등액을 $0.45 \mu \mathrm{m}$ syringe filter로 여과하고 $\mathrm{C}_{19}$ 컬럼(Nova-Pak, 4 um, 3.9×300 $\mathrm{mm}$ )이 장착된 HPLC(Agilent 1260, Waters)로 분석하였다. 분석 용매 $\mathrm{A}(140 \mathrm{mM} \mathrm{NaHAc}, 0.15 \% \mathrm{TEA}, 0.03 \% \mathrm{EDTA}$, $\left.6 \% \mathrm{CH}_{3} \mathrm{CN}\right)$, 용매 $\mathrm{B}\left(60 \% \mathrm{CH}_{3} \mathrm{CN}, 0.015 \% \mathrm{EDTA}\right)$ 를 농도구 배(A $100 \%, \mathrm{~A} 0 \%, 23 \mathrm{~min}$ ) 조건에서 $1.0 \mathrm{~mL} / \mathrm{min}$ 속도로 흘리면서 $245 \mathrm{~nm}$ 에서 detector(HP 1100 series)로 측정하였 다.

\section{총 폴리페놀 함량 측정}

총 폴리페놀 함량은 $\mathrm{AOAC}$ 법(22)에 의하여 측정하였다. 원심 분리하여 상등액을 취한 시료 $60 \mu \mathrm{L}$ 을 취하여 2 배 희석한 Folin reagent 시약을 $60 \mu \mathrm{L}$ 를 가하여 3분간 방치한 후 $10 \% \mathrm{Na}_{2} \mathrm{CO}_{3}$ 용액 $60 \mu \mathrm{L}$ 를 가하여 1시간 동안 반응시켜
반응액의 흡광도를 $700 \mathrm{~nm}$ 에서 측정하였다. 표준곡선은 gallic acid(Sigma-Aldrich)를 0, 20, 40, 60, 80, $100 \mu \mathrm{g} / \mathrm{mL}$ 용액이 되도록 조제하고, 이를 일정량 취하여 위와 같은 방법으로 $700 \mathrm{~nm}$ 에서 흡광도를 측정하여 계산하였다.

\section{알코올 함량 측정}

알코올 농도는 국세청주류분석법(23)의 증류법에 따라 측정하였다. 시료 $100 \mathrm{~mL}$ 을 증류액 $70 \mathrm{~mL}$ 이 되도록 증류한 후 증류수를 가하여 $100 \mathrm{~mL}$ 로 정용하였다. 이후 $15^{\circ} \mathrm{C}$ 로 조절하여 주정계를 넣어 알코올을 정량하였다.

\section{통계처리}

실험 결과는 Statistical Package for the Social Science (SPSS, Version 20.0, SPSS Inc., Chicago, IL, USA)를 이용하 여 평균과 표준편차 $(m e a n \pm \mathrm{SD})$ 를 구하였으며, 각 집단 간 평균치 차이를 검증하기 위하여 one way-ANOVA 및 Duncan's test를 적용하였다. 결과에 대한 검증은 $\mathrm{p}<0.05$ 수준에서 검증하였다.

\section{결과 및 고찰}

\section{$\mathrm{pH}$, 산도 및 생균수 변화}

쌀 막걸리의 고형분 함량은 $2.77 \%$, 초기 알코올 함량은 $6.0 \%(\mathrm{v} / \mathrm{v}), \mathrm{pH}$ 및 산도는 각각 $4.10,0.12 \%$ 이었으며, 효모 등 미생물의 생균수는 $9.0 \times 10^{7} \mathrm{CFU} / \mathrm{mL}$ 로 나타났다.

막걸리의 발효 과정 중 이취의 생성을 최소화시키면서, 젖산 발효를 효과적으로 수행하기 위해 $85^{\circ} \mathrm{C}$ 에서 30 분간 진공 농축하였다. 선행 실험에서 막걸리를 열처리 없이 젖 산 발효 할 경우 발효물에서 효모 발효에 의한 이취가 발생 하였으며, 이는 Choi 등(24)이 유청의 효모, 젖산 혼합발효 에서 효모 발효 시 decanoic acid, tetradecanoic acid 등의 이취 유발 성분이 젖산 발효가 진행됨에 따라 더 증가한다 는 보고와 유사한 경향을 나타내었다. 따라서 막걸리를 진 공 농축하여 효모 살균 및 알코올 제거를 수행하고, 실험의 일관성을 위해서 증발된 막걸리만큼의 멸균수를 첨가하여 젖산 발효 하였다. 고온 진공 농축하여 알코올을 제거한 $\mathrm{NAM}$ 의 초기 $\mathrm{pH}$ 및 산도는 각각 $4.2,0.50 \%$ 이었으며, 알코 올은 검출되지 않았다(not detected). 생균수 측정 결과 고초 균 등의 미생물은 $1.3 \times 10^{3} \mathrm{CFU} / \mathrm{mL}$ 로 나타났으며, 이때 젖 산균과 효모는 관찰되지 않았다. 내열성 포자를 형성하는 고초균은 동일한 열처리 조건에서 젖산균 등에 비해 열 저항성을 보이며, 발효의 최적화를 통해서 고초균의 생육 을 제어하는 것이 필요하다고 사료되었다.

$\mathrm{NAM}$ 의 발효성 당과 $\mathrm{GABA}$ 생산의 전구물질인 $\mathrm{MSG}$ 첨가에 따른 발효 효과를 검토하기 위해서 $\mathrm{MSG} 3 \%$, 포도 당 0-5\% 수준으로 혼합한 후 L plantarum EJ2014 스타터균 
주를 $1 \%$ 첨가하여 7 일 동안 젖산 발효를 수행하였다. 그 결과 포도당 $0 \%$ 와 $1 \%$ 조건의 경우 발효 1 일 차에 $\mathrm{pH} 4.15$ 로 감소한 이후 지속적으로 증가하면서 발효 7일 차에 $\mathrm{pH} 5.5$ 를 나타내었다. 반면에 포도당 $3 \%$ 와 $5 \%$ 조건의 경우 발효 전 $\mathrm{pH}$ 5.1에서 완만하게 감소하면서 발효 7일 차에 $\mathrm{pH} 4.2$ 로 낮은 값을 나타내었다(Fig. 1). 산도는 포도당 $1 \%$ 의 경우 젖산균 발효 1 일 차에 $1.50 \%$ 로 급격하게 증가한 이후 발효 3 일 차에 감소하면서 발효 초기 산도 값과 유사한 $0.50 \%$ 를 나타내었으며, 포도당 $3 \%$ 와 5\% 조건의 경우 발효 전 $0.41 \%$ 에서 발효 1 일 차에 $1.35 \%$ 로 급격하게 증가한 후 지속적으 로 증가하였으며, 발효 7일 차에 소폭 감소하여 $1.60 \%$ 를 나타내었다(Fig. 2). 포도당 $0 \%$ 와 $1 \%$ 조건의 경우 젖산 발 효가 진행되는 동안 발효물의 $\mathrm{pH}$ 가 낮아진 후 다시 높아지 며 동시에 산도가 감소하는 경향을 나타내었다. 이는 젖산 균 발효에 의해 유기산이 생성된 후 전구물질 $\mathrm{MSG}$ 로부터

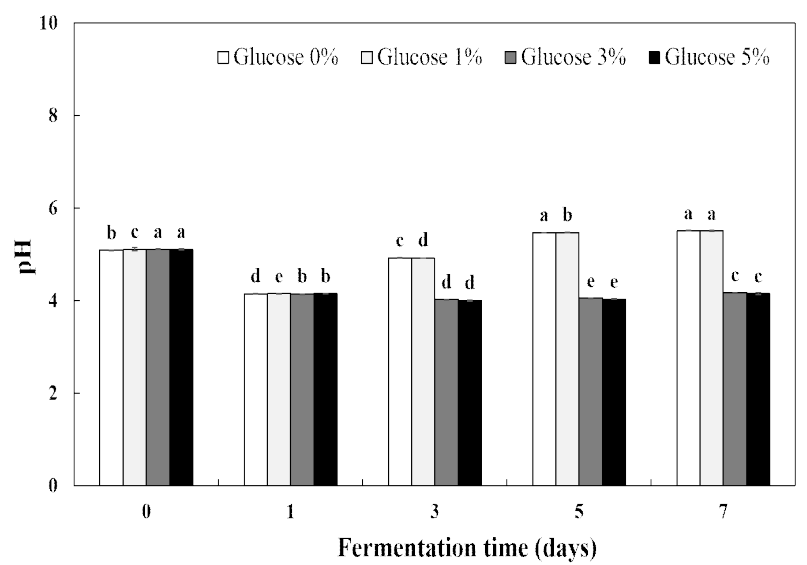

Fig. 1. Effect of glucose on the $\mathrm{pH}$ of non-alcoholic Makgeolli fermented by $L$. plantarum.

Each value is a mean $\pm \mathrm{SD}(\mathrm{n}=3)$. Different letters in the same condition mean significant difference by Duncan's multiple range test $(p<0.05)$.

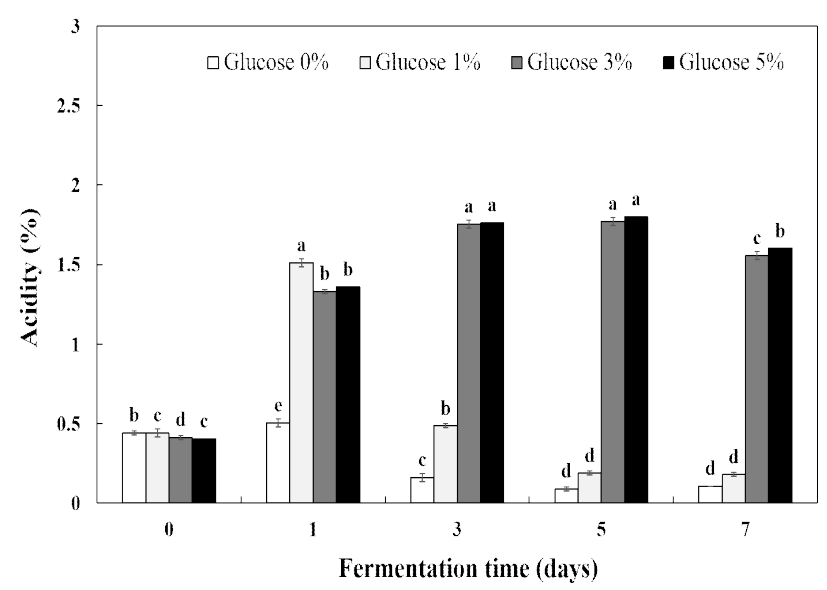

Fig. 2. Effect of glucose on the titratable acidity of non-alcoholic Makgeolli fermented by $L$. plantarum.

Each value is a mean $\pm \mathrm{SD}(\mathrm{n}=3)$. Different letters in the same condition mean significant difference by Duncan's multiple range test $(\mathrm{p}<0.05)$.
GABA가 생성되는 과정에서 proton이 소비되는 것과 관련 이 있는 것으로 판단되며, 젖산균에 의한 $\mathrm{GABA}$ 생산은 산성조건에서 적응과정으로 proton을 소비하면서 산도가 감소를 초래한다고 보고(25)한 연구와 유사한 경향을 보였 다.

생균수는 발효 1 일째 모든 조건에서 크게 증가하면서 포도당 $5 \%$ 조건에서 $3.0 \times 10^{9} \mathrm{CFU} / \mathrm{mL}$ 으로 가장 높게 나타 났다. 발효 7일 차까지 약간 감소하면서 포도당 3\%와 5\% 조건에서 $1.0 \times 10^{9} \mathrm{CFU} / \mathrm{mL}$ 로 나타났으며, 포도당 $0 \%$ 조건 은 초기 균수 $2.0 \times 10^{7} \mathrm{CFU} / \mathrm{mL}$ 까지 감소하였다. $\mathrm{NAM}$ 의 젖산 발효 과정 중 $\mathrm{MSG}$ 존재 하에서 포도당이 $3 \%$ 이상으로 첨가된 경우 발효 중에 필요한 탄소원의 충분한 공급으로 발효물의 생균수가 비교적 높은 값을 나타내었으며, 이는 포도당의 존재가 젖산균의 생균수를 높여주기 때문인 것으 로 사료되었다. 따라서 젖산균 발효 7일 차에도 높은 생균수 값의 probiotic을 함유하는 비알코올 막걸리의 젖산 발효물 을 제조할 수 있었다(Fig. 3). 이때 발효 과정 중 측정된 모든 생균수는 젖산균 발효의 전형적인 형태를 보였으며, 발효되지 않은 NAM에서는 젖산균이 관찰되지 않았으므 로 생육된 모든 젖산균은 접종균인 L. plantarum EJ2014로 사료된다.

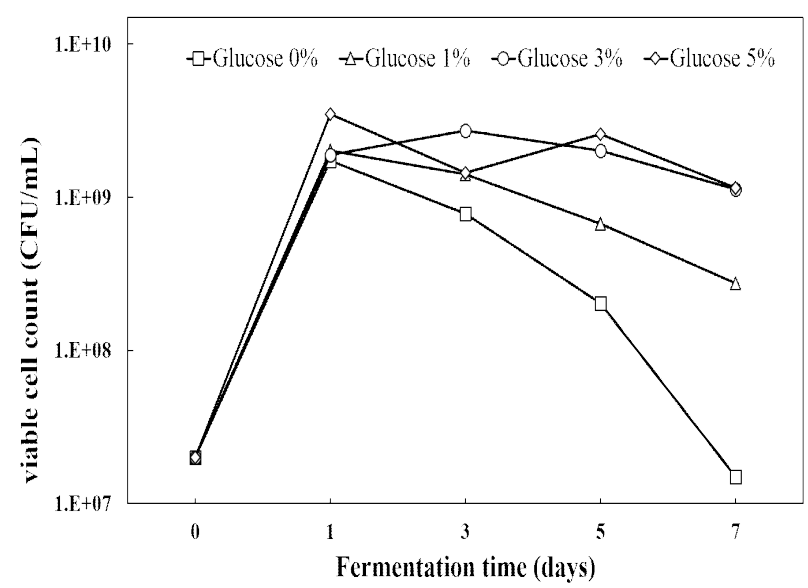

Fig. 3. Effect of glucose on the viable cell counts of non-alcoholic Makgeolli fermented by $L$. plantarum.

\section{환원당 함량 변화}

$\mathrm{DNS}$ 법으로 NAM의 발효성 당 소진을 확인하였다. NAM 의 환원당 함량을 측정한 결과 포도당 $1 \%$ 조건의 경우 발효 1 일 차에 $0.17 \%$ 로 거의 모든 환원당이 소진되었고, 포도당 $3 \%$ 조건은 발효 5일 차에, 포도당 5\% 조건은 발효 7 일 차에 거의 모든 환원당이 소진되는 것을 확인하였다 (Fig. 4). 이는 Lee와 Kwon(26)의 연구결과에서와 같이 발효 과정 중에 환원당이 감소하는 이유로는 젖산균 수가 증가됨 에 따라 lactic acid 등의 물질을 생성하는데 이용되기 때문 인 것으로 사료된다. 


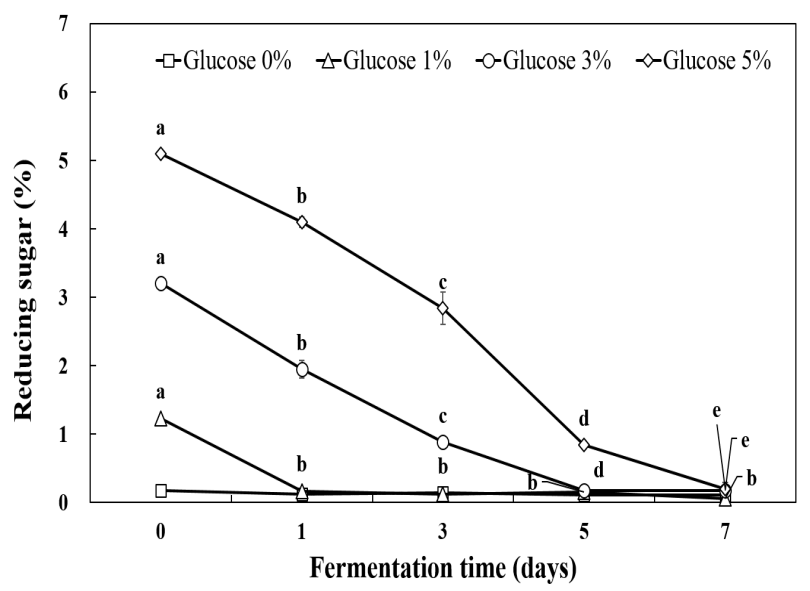

Fig. 4. Effect of glucose on the reducing sugar content of non-alcoholic Makgeolli fermented by $L$. plantarum.

Each value is a mean $\pm \mathrm{SD}(\mathrm{n}=3)$. Different letters in the same condition mean significant difference by Duncan's multiple range test $(\mathrm{p}<0.05)$.

\section{총 폴리페놀함량 비교}

$\mathrm{GABA}$ 생성에 가장 최적화되었던 포도당 $1 \%$ 조건을 비알코올 막걸리의 젖산 발효 최적조건으로 판단하여, 발 효시간에 따른 총 폴리페놀 함량을 비교 분석하였다(Table 1). 발효 전 $1,031.19 \pm 42.67 \mu \mathrm{g} / \mathrm{mL}$ 에서 발효 5일 차부터 총 폴리페놀함량이 소폭 증가하여 $1,192 \pm 44.90 \mu \mathrm{g} / \mathrm{mL}$ 로 나타났으며, 발효 7일째에 $1,478.98 \pm 56.50 \mu \mathrm{g} / \mathrm{mL}$ 으로 유의 적으로 높아진 값을 나타내었다. 이는 유산균 균주에 의한 톳 추출액의 폴리페놀함량이 평균 $815.71 \mathrm{mg} / \mathrm{g}$ 증가했다고 보고한 연구 결과(27)와 유사한 경향을 나타내었다.

Table 1. Changes in polyphenol content of non-alcoholic Makgeolli fermented by $L$. plantarum EJ2014

\begin{tabular}{cccccc}
\hline & \multicolumn{5}{c}{ Fermentation time (days) } \\
\cline { 2 - 6 } & 0 & 1 & 3 & 5 & 7 \\
\hline Polyphenol content & $1,031.19$ & $1,004.77$ & $1,000.77$ & $1,192.56$ & $1,478.98$ \\
$(\mu \mathrm{g} / \mathrm{mL})$ & $\pm 42.67^{1)(2)}$ & $\pm 38.89^{\mathrm{c}}$ & $\pm 67.75^{\mathrm{c}}$ & $\pm 44.90^{\mathrm{b}}$ & $\pm 56.50^{\mathrm{a}}$ \\
\hline
\end{tabular}

${ }^{1)}$ Each value is a mean $\pm \mathrm{SD}(\mathrm{n}=3)$.

${ }^{2}$ Different letters in the same condition mean significant difference by Duncan's multiple range test $(\mathrm{p}<0.05)$.

\section{$\mathrm{GABA}$ 생성능 및 $\mathrm{MSG}$ 소진능}

포도당 농도에 따른 젖산균 발효물의 $\mathrm{MSG}$ 소진과 GABA 생성을 비교하기 위해서 TLC plate를 이용하여 확인 한 결과 포도당 $1 \%$ 조건에서 발효 5일 차에 대부분의 MSG 가 소진되어 $\mathrm{GABA}$ 로 전환된 것으로 나타났다. 포도당 $0 \%$ 조건의 경우 $\mathrm{MSG}$ 의 잔존량이 가장 많은 것으로 나타났으 며, 포도당 $3 \%$ 와 $5 \%$ 조건의 경우 $0 \%$ 조건보다 $\mathrm{MSG}$ 가 조금 더 소진되었으나, 발효 7일 차에 여전히 MSG가 잔존 하는 것으로 나타났다(Fig. 5). 이는 GABA 생성에서 초기 당 농도가 주요 인자로 작용한 것으로 사료되었다. 환원당 결과에서 포도당 $1 \%$ 조건의 경우 발효 1 일 차에 대부분의 환원당이 소진된 반면, 포도당 $3 \%$ 와 $5 \%$ 조건의 경우 발효 5 일 차 이후에 환원당이 소진되는 것으로 나타났다. 이를 통해 젓산균 발효에서 기질인 MSG로부터 GABA를 생성할 때 발효성 당의 농도가 매우 중요한 변수로 작용하는 것을 확인하였으며, 이는 Lee등(28)의 보고와 유사한 경향을 나 타내었다. MSG가 첨가된 천연물을 배지로 이용하여 젖산 균에 의한 GABA 생산에서 초기 포도당 농도가 비교적 낮은 조건이 높은 경우보다 GABA 생산이 효율적으로 진행 되었다. 이는 발효성 당이 너무 많을 경우 젖산균이 MSG가 아닌 포도당을 먼저 이용함으로써 $\mathrm{MSG}$ 의 소진이 효율적 이지 않았기 때문으로 판단되었다. 녹각 추출액을 원료로 하여 L. plantarum에 의한 GABA 생산에서 초기 포도당 농도가 중요한 인자임을 보고하였다(29). 따라서 NAM에 기능성 물질인 GABA와 probiotic을 강화시키는 젖산균 발 효 최적화 연구에서 열처리에 의해서 알코올을 제거시킨 비알코올 막걸리에 발효성 당으로 포도당 $1 \%$ 와 전구물질 $\mathrm{MSG} 3 \%$ 수준으로 첨가하여 젖산 발효시키는 것이 $\mathrm{GABA}$ 생산에 최적 조건이라고 판단하였다.

또한 선행연구에서 쌀 막걸리와 쌀 분말 희석액의 가수 분해 유무에 따른 GABA 생성능 비교 실험을 진행한 결과 가수분해 유무에 관계없이 쌀 분말 희석액에서는 젖산 발효 15 일 이상 진행하여도 첨가한 MSG $3 \%$ 가 대부분 잔존함을 확인하였다(data not shown). 반면에 NAM에 젖산 발효를 진행할 경우 발효 5일 차에 대부분의 MSG가 GABA로 전환 되는 것으로 나타났으며, 이는 발효 기간을 10 일 이상 단축

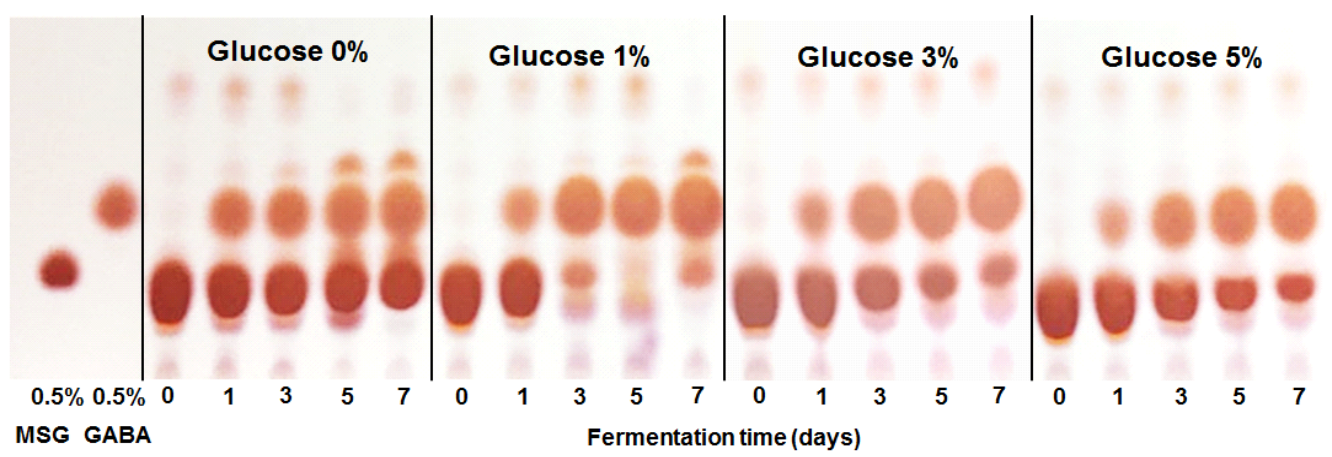

Fig. 5. Effect of glucose on the GABA production of non-alcoholic Makgeolli fermented by L. plantarum (TLC analysis). 
시키는 매우 의미있는 결과이다. 이에 효모와 코지 등의 대사산물이 쌀 발효에 있어서 GABA 생산과 MSG 소진에 중요한 인자라고 판단하였다.

$\mathrm{HPLC}$ 를 이용하여 포도당 $1 \%$ 조건의 발효 전, 후의 기질 인 glutamic acid와 GABA함량을 정량 분석하였다(Table 2). 발효 전 glutamic acid는 $2.54 \%$ 에서 발효 7일 후 $0.06 \%$ 로 $100 \%$ 에 가까운 소진율을 보였으며, $\mathrm{GABA}$ 는 발효 전 $0.00 \%$ 에서 발효 7 일 후 $1.59 \%$ 함유하고 있는 것을 확인하 였다.

Table 2. Changes in glutamic acid and GABA contents of non-alcoholic Makgeolli

\begin{tabular}{ccc}
\hline & Before fermentation & After fermentation \\
\hline Glutamic acid & $2.54 \%$ & $0.06 \%$ \\
GABA & 0.00 & $1.59 \%$ \\
\hline
\end{tabular}

$\mathrm{NAM}$ 의 젖산 발효 과정에서 탄소원의 농도가 $\mathrm{GABA}$ 생산에 크게 영향을 미치는 것으로 사료되며, 발효성 당으 로 탄소원이 너무 많으면 젖산균의 대사산물인 유기산 생성 의 증가로 $\mathrm{pH}$ 가 크게 감소하고 산도가 높아지면서 glutamate decarboxylase(GAD) 효소 활성이 억제되는 것으 로 사료되었다. 콩과 해조류 추출액의 Aspergillus oryzae와 Lactobacillus brevis 혼합발효를 통한 GABA 생산에서 발효 성 당의 무 첨가 및 $\mathrm{pH} 5.0$ 조건이 최적 발효조건인 것으로 보고한 Jang 등(30)의 연구 결과와 비교했을 때, 젖산 발효 를 통한 GABA 생산에서 배지의 영양성분이 중요하며, 특 히 질소원과 탄소원의 농도가 중요한 인자로서 작용하기 때문인 것으로 사료되었다. 또한 천연물을 배지로 이용한 GABA 생산에서 필수 영양성분으로 yeast extract(YE)가 첨가되는 경우와는 대조적으로 NAM에서 $\mathrm{YE}$ 첨가 없이도 젖산균에 의해서 효과적으로 $\mathrm{GABA}$ 를 생산한 연구결과는 다른 연구결과와 차이가 있다.

천연물 추출물의 젖산균 발효를 통한 $\mathrm{GABA}$ 생산에서 배지의 성분조성이 GABA 생산에 영향을 미치며, 특히 YE 의 존재가 $\mathrm{GABA}$ 전환에 절대적으로 영향을 주는 것으로 보고(29)되었지만, D'Mello(31)의 연구와 Kim 등(25)의 연 구를 바탕으로 보아 YE첨가 없이도 막걸리 제조시에 효모 발효로부터 생성된 대사산물과 glutamate decarboxylase의 조효소인 pyridoxal-5-phosphate(PLP)등이 존재하여 젖산 균 발효시에 $\mathrm{GABA}$ 생성에 기여하는 것으로 사료되었다. 또한 젖산 발효 1 일 차 이후로 생균수가 완만하게 감소하였 지만 GABA 생성에 큰 영향을 미치지 않은 결과는 $\mathrm{Kim}$ 등(14)의 연구와 유사한 경향을 나타내었다.

결론적으로 쌀 코지 및 효모발효에 의해서 생산되는 쌀 막걸리는 효소작용에 의한 가수분해물과 다양한 대사산물 을 함유하며, 특히 효모발효는 알코올 이외에 다양한 영양 성분을 제공함으로서 젖산균 발효를 위한 환경을 만드는
것으로 판단되었다. 따라서 $\mathrm{NAM}$ 에 기질인 $\mathrm{MSG}$ 를 추가적 으로 첨가하여 젖산균 발효를 통해서 효과적으로 기능성물 질인 $\mathrm{GABA}$ 로 전환시킬 수 있었으며, 고농도 $\mathrm{GABA}$ 및 probiotic가 강화된 비알코올 막걸리는 건강소재 및 다양한 음료의 기능성 원료로 활용이 가능할 것으로 판단되었다.

\section{요 약}

본 연구에서는 전통주인 막걸리로부터 비알코올 막걸리 를 제조한 후 젖산균 발효 최적화를 통해서 기능성물질 $\mathrm{GABA}$ 및 probiotic가 강화된 기능성 쌀 발효물 소재를 개발 하였다.

젖산균의 생육을 저해하는 효모의 활성을 저해하기 위하 여 쌀 막걸리를 $85^{\circ} \mathrm{C}$ 에서 30 분간 열처리하여 비알코올 막걸 리를 제조하였다. 이에 MSG $3 \%$ 와 포도당 $1 \%$ 를 첨가한 후 L. plantarum EJ 2014 스타터를 $1 \%$ 접종하여 $30^{\circ} \mathrm{C}$ 에서 7 일간 젖산균 발효를 진행하였다. 젖산균 발효 시 $\mathrm{pH}$ 가 5.12 에서 5.49 로 증가하였으며 산도는 발효 전 $0.41 \%$ 에서 발효 1 일 차에 $1.5 \%$ 로 증가한 이후 감소하여 발효 7 일 차에 $0.2 \%$ 를 나타내었다. L. plantarum EJ2014 생균수는 발효 초기 $2.0 \times 10^{7} \mathrm{CFU} / \mathrm{mL}$ 에서 발효 1 일 차에 $2.0 \times 10^{9} \mathrm{CFU} / \mathrm{mL}$ 로 증가하였다가 이후 $3.0 \times 10^{8} \mathrm{CFU} / \mathrm{mL}$ 로 지속적으로 감소 하였다. TLC 분석을 통해서 젖산 발효 5 일 차 이후에 MSG 가 모두 소진되어 $\mathrm{GABA}$ 로 전환되는 것을 확인할 수 있었 으며, HPLC를 이용한 정량분석에서 초기 MSG $2.54 \%$ 에서, 발효 7일에 GABA $1.59 \%$ 로 모두 전환되는 것을 확인하였 다. 포도당 $1 \%$ 조건에서 비알코올 막걸리의 젖산 발효 7 일 까지 총폴리페놀 함량이 증가하는 경향을 보여 $1,478.98 \pm 56.50 \mu \mathrm{g} / \mathrm{mL}$ 로 나타났다.

결론적으로 곰팡이 코지 및 효모의 대사산물을 함유한 비알코올 쌀 막걸리에 젖산균 발효 최적화를 통해서 기능성 물질인 $\mathrm{GABA}$ 와 젖산균 probiotic을 $10^{8} \mathrm{CFU} / \mathrm{mL}$ 이상 함유 한 쌀 발효물을 제조할 수 있었으며, 이를 통해 다양한 음료 및 기능성 식품에서 원료 베이스로의 활용이 기대된다.

\section{감사의 글}

본 연구는 농림축산식품부의 재원으로 농림수산식품기 술기획평가원이 기술사업화지원사업(No. 314082-3)지원 과 중소벤처기업부 지원 계명 대학교 전통미생물자원개발 및 산업화연구센터에 의해 연구되었음.

\section{Reference}

1. Min JH, Baek SY, Lee JS, Kim HK (2011) Changes 
of yeasts and bacterial flora during the storage of Korean traditional Makgeolli. Kor J Mycol, 39, 151-153

2. Lee DH, Kim JH, Lee JS (2009) Effect of pears on the quality and physiological functionality of Makgeoly. Korean J Food Nutr, 22, 606-611

3. Kim SM, Cho WK (2006) Effect of Takju (Korean turbid rice wine) lees on the serum glucose levels in streptozotocin-induced diabetic rats. Korean J Food Culture, 21, 638-643

4. Lee SJ, Kim JH, Jung YW, Park SY, Shin WC, Pakr CS, Hong SY, Kim GW (2011) Composition of organic acids and physiological functionality of commercial Makgeolli. Korean J Food Sci Technol, 43, 206-212

5. Shin MO, Kang DY, Kim MH, Bae SJ (2008) Effect of growth inhibition and quinone reductase activity stimulation of Makgeoly fractions in various cancer cells. J Korean Soc Food Sci Nutr, 37, 288-293

6. Ha JH, Shim YS, Cho YS, Seo DW, Jang HW, Jang HJ (2014) Analysis of E,E-farnesol and squalene in Makgeolli using stir bar sorptive extraction coupled with gas chromatography-mass spectrometry. Anal Sci Technol, 27, 60-65

7. Shin SJ, Kim SW, Chung HC, Han GD (2015) Characteristics of GABA rice Makgeolli made by Korean traditional rice wine method of Geupchungju. J Korean Soc Food Sci Nutr, 44, 573-578

8. Jo SJ, Oh SM, Jang EK, Hwang K, Lee SP (2008) Physicochemical properties of carrot juice fermented by Leuconostoc mesenteroides SM. J Korean Soc Food Sci Nutr, 37, 210-216

9. Komatsuzaki N, Shima J, Kawamoto S, Momose H, Kimura T (2005) Production of $\gamma$-aminobutyric acid (GABA) by Lactobacillus paracasei isolated from traditional fermented foods. Food Microbiol, 22, 497-504

10. Ha GJ, Kim NK, Je HJ, Choi SY, Seol HK, Hong GP, Lee SD (2015) Quality characteristics of Makgeolli produced in Gyeongnam province. J Agric Life Sci, 49, 247-257

11. Diana M, Quilez J, Rafecas M (2014) Gamma-aminobutyric acid as a bioactive compound in foods: a review. J Funct Foods, 10, 407-420

12. Cho SC, Kim DH, Park CS, Koh JH, Pyun YR, Kook MC (2012) Production of GABA-rich tomato paste by Lactobacillus sp. fermentation. Korean J Food Nutr, 25, 26-3

13. Li H, Cao Y (2010) Lactic acid bacterial cell factories for gamma-aminobutyric acid. Amino Acids, 39,
1107-1116

14. Kim JY, Lee MY, Ji GE, Lee YS, Hwang KT (2009) Production of $\gamma$-aminobutyric acid in black raspberry juice during fermentation by Lactobacillus brevis GABA 100. Int J Food Microbiol, 130, 12-16

15. Park YJ (2014) Study of anti-inflammatory efficacy of GABA enriched cacao fermentation by lactic acid bacteria. MS Thesis, Kyunghee University, Korea, $\mathrm{p}$ 27-37

16. Lee YS, Song TY, Kong WS, Yoon MH (2013) Characterization of $\mathrm{\gamma}$-aminobutyric acid (GABA) produced by a lactic acid bacterium from button mushroom bed. J Mushroom Sci Prod, 11, 181-186

17. Sawai Y, Yamaguchi Y, Miyama D, Yoshitomi H (2001) Cycling treatment of anaerobic and aerobic incubation increases the content of $\gamma$-aminobutyric acid in tea shoots. Amino Acids, 20, 331-334

18. Park EJ, Lee SO, Lee SP (2017) Dvelopment of natural fermented seasoning with Flammulina velutipes powder fortified with $\gamma$-aminobutyric acid (GABA) by lactic acid fermentationm. Korean J Food Preserv, 24, 237-245

19. AOAC (1990) Official methods of analysis. $15^{\text {th }} \mathrm{ed}$, Association of official analytical chemists. Washington DC, USA, p 13

20. AOAC (1990) Official methods of analysis. $15^{\text {th }}$ ed, Association of official analytical chemists. Washington DC, USA, p 777-784

21. Miller GL (1959) Use of dinitrosalicylic acid reagent for determination of reducing sugar. Anal Chem, 31, 426-428

22. AOAC (1990) Official methods of analysis. $15^{\text {th }}$ ed, Association of official analytical chemists. Washington DC, USA, p 1077-1918

23. Kim SH, Park JM, Yoon HS, Song DN, Song IG, Eom HY (2013) Physiological and sensory characteristics of Makgeolli with added paprika (Capsicum annuum L). Korean J Food Sci Technol, 45, 578-582

24. Choi SI, Kang SA, Cheong C (2013) Yeast selection for quality optimization of distilled spirits. Journal of Korea Academia-Industrial Cooperation Society, 14, 3887-3896

25. Kim JA, Park MS, Kang SA, Ji GE (2014) Production of $\gamma$-aminobutyric acid during fermentation of Gastrodia elata $\mathrm{Bl}$. by co-culture of Lactobacillus brevis GABA 100 with Bifidobacterium bifidum $\mathrm{BGN}_{4}$. Food Sci Biotechnol, 23, 459-466

26. Lee SS, Kwon DJ (2015) Quality characteristics of kimchi 
with Artemisia annua extracts. Korean J Food Preserv, 22, 666-673

27. Song HS, Kim HK, Min HO, Choi JD, Kim YM (2011) Changes in physicochemical and sensory properties of Hizikia fusiforme water extract by fermentation of lactic acid bacteria. Kor J Fish Aquat Sci, 44, 104-110

28. Lee HS, Kwon SY, Lee SO, Lee SP (2016) Production of fermented Omija (Schizandra chinensis) beverage fortified with high content of gamma-amino butyric acid using Lactobacillus plantarum Korean J Food Preserv, 23, 326-334

29. Kwon SY (2017) Production of $\gamma$-amino butyric acid (GABA) in old antler fermented by Lactobacillus plantarum and evaluation of bioactive property. MS Thesis, Keimyung University, Korea, p 33-37
30. Jang EK, Kim NY, Ahn HJ, Ji GE (2015) r-Aminobutyric acid (GABA) production and angiotensin - I converting enzyme (ACE) inhibitory activity of fermented soybean containing sea tangle by the co-culture of Lactobacillus brevis with Aspergillus oryzae. J Microbiol Biotechnol, $25,1315-1320$

31. D'Mello JPF (2017) The yeast y-aminobutyrate GABA shnt, The handbook of microbial metabolism of amino acids. CABI, Edinburgh, UK, p 29-48 